\title{
HIV-AIDS, is not a Viral Disease; It is a Metabolic Syndrome
}

Biswaroop Roy Chowdhury

Medical Nutritionist, Indo-Vietnam Medical Board, India

*Corresponding author: Biswaroop Roy Chowdhury, Medical Nutritionist, Indo-Vietnam medical Board, India, Tel: +919810996229; E-mail: biswaroop@biswaroop.com Received date: March 12, 2018; Accepted date: March 15, 2018; Published date: March 19, 2018

Copyright: () 2018 Chowdhury BR. This is an open-access article distributed under the terms of the creative commons attribution license, which permits unrestricted use, distribution, and reproduction in any medium, provided the original author and source are credited.

\begin{abstract}
In the past 3 decades, we have been living with the hypothesis that, "HIV causes AIDS." HIV, Human Immunodeficiency Virus is considered as the causative agent of AIDS, Acquired Immunodeficiency Syndrome; wherein the body's immune system gets damaged opening doors for major infections. However, the 3 Noble prize winner prestigious scientists including Luc Montagnier (discovered HIV), Kary Mullis (invented PCR test for HIV detection), and Wangari Maathai, (renowned African environmentalist), along with thousands of other scientists and intellects worked on the other side of the coin to prove back and again that the above said theory is a misconception. Last 35 years have provided immense literature and investigation evidences to firmly conclude that HIV is not the real cause of AIDS. On the other hand, malnutrition and metabolic syndrome due to drug abuse have been pointed as the real convicts. This review article revolves around the same theory for better understanding the HIV-AIDS hypothesis to be fallacious and search for valid causes.
\end{abstract}

Keywords: HIV; AIDS; HIV causes AIDS; Viral Disease; AZT

\section{Introduction}

The idea that AIDS is caused by a virus was introduced by Dr. Robert Gallo, a researcher of National Institute of Health, USA [1-4]. On April 23, 1984, in an international press conference, Gallo announced his discovery of a new virus to be the probable cause of AIDS. He announced his hypothesis without providing any evidences in support, thereby, violating the scientific protocol; as a researcher must first publish his claim in a medical journal for experts to examine, duplicate the findings with experiments and establish the hypothesis [5-7]. After several days of announcement of HIV-AIDS hypothesis; Gallo published his paper to support the idea, whereas, even in his paper, he could not relate HIV virus to most of the AIDS patients [8]. This article aims to review the HIV-AIDS hypothesis introduced 34 years back, with the prime objective to investigate two major aspects:

\section{Is HIV the cause of AIDS? \\ II. If not HIV, then what causes AIDS!}

\section{Does HIV cause AIDS?}

There have been several loop holes and errors in the diagnostic protocols for HIV detection. According to the Koch's postulates, to establish a virus (or microorganism), as a causative agent of a disease, the virus must be found in all the cases of the disease. However, as mentioned in the Introduction, in the paper published by Gallo, he could not find the virus in all the AIDS patients subject to his study [9].

Listed under are the other major evidences to support that HIV may not be the cause of AIDS:

I. In 1984, CDC (Centers for Disease Control) scientists reported that the positive HTLVIII/LAV, Human T-cell lymphotropic virus Type III/lymphadenopathy-associated virus (the name originally used for
HIV) antibody test cannot establish whether the person is currently infected by the virus or not [6].

II. In 1996, Johnson reported about 60+ factors which may result in false positive test for HIV antibodies in ELISA or Western Blot test [10]. It is important to note that factors included - malaria, flu, vaccinations and even pregnancy in women. These findings and evidences were published in highly regarded journals including AIDS, Lancet and the Journal of American Medical Association [10].

III. In 2010, Bauer reported that the standard criteria to detect the presence of HIV in Western Blot test are p41 and p24 - proteinantigens, which can also be found in the blood platelets of a HIV noninfected/healthy individual. This meant that the marker used to establish the presence of HIV in a person is not specific to HIV or even AIDS patients. Even a healthy person may test HIV positive in western blot test and may not carry HIV at all [11].

IV. Kary Mullis, the inventor of PCR test and a Nobel Prize winner stated that, it is inappropriate and incompatible to count or estimate the quantity of virus percentage, as the test can only detect proteins, which are in some cases mistakenly believed to be unique to HIV. Furthermore, the test can detect genetic sequences of the virus, but not the virus themselves [12].

V. Human endogenous retrovirus or HERVs are produced by the body itself during illness or as by-products on cell death. These HERVs are particle like and very similar to retrovirus [13]. Hence, the genetic sequences detected by PCR test may not be those from an exogenous virus at all and may explain the false positive test $[11,14]$. Similarly, the HERVs can be reactive when testing for HIV antibodies (ELISA, Western blot test) and may also result in false positive [15].

With the support of all the above evidences, we can conclude that HIV may not be the cause of AIDS. Thereafter, the obvious question is - "What causes AIDS?" 
Page 2 of 3

\section{What causes AIDS? Is it a Metabolic Syndrome?}

According to Koch's postulate's 2nd principle (see 1st principle in the above section), to establish a virus as a causative agent of the disease, it must be isolated from the diseased body and cultivated as a pure culture. However, HIV has never been isolated from a human body, as is reported by Etienne de Harven in 2010. He stated that all the images of particles supposedly representing HIV and published in scientific journals; did not come directly from AIDS patients [16,17]. It may be noted that Etienne is the scientist who presented the first electron micrograph of mouse leukemia virus in 1960 [9].

If not HIV, what may cause AIDS? The following evidences suggest metabolic syndrome and chemical ingestion to be the prime causes of AIDS.

I. Oxidative stress reduces the cells ability to absorb oxygen leading to cell's death. Oxidative stress has been associated with many medical conditions including metabolic syndrome, diabetes type 2 and cancer [18-20]. Homosexuals, diagnosed as HIV positive or suffering from AIDS, are also found to be drug abusers, these drugs are potent oxidizing agents. Even Luc Montagnier (co-discoverer of HIV and a Noble prize winner) suggested use of anti-oxidants for the treatment of HIV/AIDS patients [21,22].

II. The research on Nitric oxide (NO) was still in its infancy at the time when HIV-AIDS hypothesis was proposed [18]. Now, it is well recognized that $\mathrm{NO}$ is an important signaling molecule in activation of immune system [23]. Adequate level of NO is required to regulate the blood pressure, blood sugar, metabolic activities and for defense mechanisms. However, the excessive amount of NO may lead to T-cell depletion (one of the AIDS defining factor), inflammation, infection and metabolic syndrome [24,25]. The excess of NO is caused by factors like Nitrate Inhalation (example- using poppors), immunotoxic medications (example-taking antiretrovirals) and many other factors which are commonly found among homosexual's HIV positive individuals [18]. Drug use but not sexual behavior is the major risk factor for homosexual HIV positive population [24]. Even prostitutes may not contract HIV unless they are habitual drug addicts [26,27].

III. In 1985, Dr. Anthony Fauci, the director of NIAID (National Institute of Allergy and Infectious Diseases) reported that the major cause of immune deficiency diseases is malnutrition, which is most prevalent in developing regions like Africa, where diseases like measles affect millions of lives [28]. Malnutrition, crowded living conditions and poverty are known to be common around the globe especially among AIDS affected countries/regions. Malnutrition in an expectant mother may sometimes lead to lifelong immune-suppressive effects [29]. Also, infections due to malnutrition led immunodeficiency are the world's leading cause of death among infants [29].

IV. Immuno-suppressive effects of pharmaceutical drugs including drugs prescribed for AIDS patients like AZT (azidothymidine) etc, chemotherapy and recreational drug abuse, are all known to cause pneumonia, mouth sores, fever \& night sweats, which are associated medical symptoms for AIDS [30].

V. Stress, anxiety \& depression are known to cause compromised immune system and result in symptoms identical to AIDS [31]. Mental Stress leads to increased production of cortisol, which often causes reduction in T-cells, resulting in production of HERVs (as discussed before in the article) leading to false HIV positive diagnosis and AIDS like symptoms.

\section{Conclusion}

AIDS is not a new illness with which humanity is suffering from the past 34 years or so. In fact, it is a collection of 29 familiar diseases (including pneumonia, tuberculosis, certain kinds of cancer, diarrhea etc) collectively given a name called AIDS. As, according to CDC (Centers for Disease Control), if a patient with any of these 29 diseases is also tested positive for HIV; then will be considered as an AIDS patient. For example, if a person suffering from tuberculosis is also tested HIV positive, then the illness will be called as AIDS, otherwise it will be only tuberculosis. However, all kinds of HIV detection tests themselves have loopholes with big chances of errors and false positive results, as is demonstrated in the first section of the article. Unreliability of these tests can be well understood by the fact that, the court of law does not consider the evidences to prove an individual's HIV status to be legally correct, as is evident from the court's decision released by Office of Medical and Scientific Justice (OMSJ) in 2015. On February 23, 2015, the U.S Military appealed court to overturn the HIV conviction of sentencing a sergeant to 8 years jail term, convicted for attending a sex party and disclosing his HIV positive status. The court ruled that the evidence to test his HIV status is legally insufficient [32]. Considering the above discussion, it can be well concluded that, "HIV-AIDS is not a viral disease; it is a metabolic syndrome."

\section{References}

1. Babich B (2015) Calling Science Pseudoscience: Fleck's Archaeologies of Fact and Latour's Biography of an Investigation in AIDS Denialism and Homeopathy. Internat Stud Philos 29: 1-39.

2. Farber C (1994) HIV \& AIDS - Interview with Kary Mullis. AIDS, Words from the Front.

3. Lawson T (2007) Doctors and Nobel Laureate suggest HIV-AIDS is bioterrorism.

4. Duesberg P, Rasnick D (1998) The AIDS dilemma: drug diseases blamed on a passenger virus. Genetica 104: 85-132.

5. Mullis K (1998) Dancing Naked in the Mind Field Pantheon Books.

6. Shenton J (1998) Positively False Exposing the Myths around HIV and AIDS.

7. Altman LK (1984) Researchers Believe AIDS Virus is Found. The New York Times.

8. Gallo RC (1984) Gallo found HIV in only 26 of 63 AIDS patients, AHistoricalSummaryofGallo.pdf.

9. Centers for Disease Control (1984) Antibodies to a retrovirus etiologically associated with acquired immunodeficiency syndrome (AIDS) in populations with increased incidences of the syndrome. The Journal of the American Medical Association 33: 377-379.

10. Johnson C (1996) HIV \& AIDS - Whose antibodies are they anyway? Factors Known to Cause False Positive HIV Antibody Test Results.

11. Bauer HH (2010) HIV Tests Are Not HIV Tests. Journal of American Physicians and Surgeons 15: 5-9.

12. Lauritsen J (1996) HIV \& AIDS - Has Provincetown Become Protease Town. New York Native.

13. Nelson P (2003) Demystified... human endogenous retroviruses. Molecular Pathology 56: 11-18.

14. Owens DK (1996) Polymerase Chain Reaction for the Diagnosis of HIV Infection in Adults. Ann Intern Med 124: 803-815.

15. Singh SK (2007) Endogenous retroviruses: suspects in the disease world. Future microbiology 2: 269-275.

16. de Harven E (2010) Human Endogenous Retroviruses and AIDS Research: Confusion, Consensus, or Science? Journal of American Physicians and Surgeons 15: 69-74. 
Citation: Chowdhury BR (2018) HIV-AIDS, is not a Viral Disease; It is a Metabolic Syndrome. J Metabolic Synd 7: 239. doi: 10.4172/2167-0943.1000239

Page 3 of 3

17. Culshaw R (2007) Science Sold Out: Does HIV Really Cause AIDS? North Atlantic Books, Berkeley, CA.

18. Kremer H (2012) The Silent Revolution in Cancer and AIDS Medicine. Xlibris Corporation.

19. Null G (2002) AIDS-A-Second-Opinion. Seven Stories Press, New York.

20. Watson JD (2014) Hypothesis Type 2 diabetes as a redox disease. The Lancet 383: 841-843.

21. Gougeon ML, Montagnier L (1993) Apoptosis in AIDS. Science 260: 1269-1270.

22. Eleopulos EP, Turner VF, Papadimitriou JM, Causer D, Thomas BH, et al (1996) A critical analysis of the HIV- T4-cell-AIDS hypothesis. Genetics and Evolution 3-22.

23. Aktan F (2004) iNOS-mediated nitric oxide production and its regulation. Life Sciences 75: 639-653.

24. Lechner M, Lirk P, Rieder J (2005) Inducible nitric oxide synthase ( iNOS ) in tumor biology: The two sides of the same coin. $15: 277-289$.

25. Page-Shafer K, Veugelers PJ, Moss AR, Strathdee S, Kaldor JM, et al. (1997) Sexual risk behavior and risk factors for HIV-1 seroconversion in homosexual men participating in the tricontinental seroconverter study, 1982- 1994. Am J Epidemiol 146: 531-542.

26. Rosenberg MJ, Weiner JM (1988) Prostitutes and AIDS: A health department priority? Am J Public Health 78: 418-423.

27. Fiala C (2000) HIV \& AIDS - Epidemiological evidence against heterosexual transmission of HIV and against prevention-campaigns.

28. Willner RE (1994) Deadly deception. The proof that sex and HIV absolutely do not cause AIDS.

29. Chandra RK (1983) Nutrition, immunity, and infection: present knowledge and future directions. Lancet 321: 688-691.

30. Lane KAG (1999) The Merck Manual: A Century of Medical Publishing and Practice.

31. Benson H (1997) The nocebo effect: History and physiology. Preventive Medicine 26: 612-615.

32. Office of Medical and Scientific Justice (2015) Military Appeals Court Overturns HIV Conviction. 